\title{
MINIREVIEW
}

\section{ADENOSINE DEAMINASE DEFICIENCY AND SEVERE COMBINED IMMUNODEFICIENCY DISEASE}

MartIn B. Van der Weyden and William N. Kelley

Department of Medicine, Monash Unfversity, Australia

and Departments of Internal Medicine and Blological Chemistry,

Untversity of Michigan, Ann Arbor, Michigan, U.S.A.

\section{SUMMARY}

The nature of the assoctation of adenosine deaminase deficlency and severe combined immunodeficlency disease is reviewed. The basis for the molecular heterogenetty exhibited by adenosine deaminase in human tissue and the mechanisms whereby a deficiency of this activity results in the extreme perturbation of the Immune system as observed In severe combined immunodeficlency are critically discussed.

Severe combined Immunodeficlency (SCID) is a disorder of infancy characterized by defects of both cellular and humoral Immunity with a uniformly fatal outcome if untreated. In a group of patients with the autosomal recessive form of SCID, a deficlency of adenosine deaminase activity (adenosine aminohydrolase EC 3.5.4.4, ADA) has been extensively documented (1-4). Since the deficiency of this activity, which catalyses the hydrolytic deamination of adenosine to produce inosine, represents the first association of a specific enzyme defect with an inherited disorder of $T$ and $B$ cell function, the nature of this assoclation is of some significance. It has been suggested that the enzyme deficiency and the disease atate are causally related. Alternatively, this association could reflect a deletion fortultously involving the locus for ADA and a closely linked locus controlling immume function (1).

The purpose of this communication is to review the characteristics of ADA occurring in human tissue and to consider the possible mechanisms whereby a deficlency of this activity in patients with SCID could be related to the observed immunological dysfunction.

\section{Nature of the Molecular Heterogene1ty of ADA in Human Tissue}

In human tissue ADA exhibits considerable molecular heterogeneity (5-11). The ADA activity of human erythrocytes displays several forms which were flrst demonstrated by their differing electrophoretic mobility

Abbreviations: ADA, adenosine deaminage; SCID, severe combined Immunodeficiency; T cell, thymus derived 1ymphocytes; B cell, bursa derlved lymphocyte; PRPP, phosphorlbosylpyrophosphate; EHNA, erythro-9 (2-hydroxy1-3-nonyl) adenine. 
in starch gel (5). The predominance of one of several electrophoretic phenotypes in human erythrocytes was attributed to a genetic polymorphism due to two allelic genes on an autosome termed $\mathrm{ADA}_{1}$ and $\mathrm{ADA}_{2}$. Human t1ssues other than erythrocytes were reported to have severa1 additional electrophoretic forms of ADA designated a to e, and termed "tissue specific" Isoenżymes. Isoenzyme a was noted only in lung and 11ver extracts, 1soenzyme e In kldney and Intestinal extracts while lsoenzymes $b$, $c$ and $d$ were widely distributed. While the molecular welght of human erythrocyte ADA was reported to range from 30,000 to $35,000(9,10)$, the molecular weight of ADA in other tisgues was reported to be from 280,000 to 440,000 (7).

More recent studies on the molecular welght and interconvertibility of the various forms of human ADA have helped to clarify the nature of the molecular heterogenelty of the enzyme (8, 12-15). Akedo and his coworkers reported two forms of ADA with molecular weights of 47,000 and 230,000. The large form occurred only in lung and liver extracts, while the small form was found in leukocyte preparations; in gastric tissue a mixture of the two specles was present (8). An interrelationshtp between the two forms of ADA was suggested by their demonstration that the small form of the enzyme could be converted to the large spectes by a specific proteln which they termed "conversion factor" (12). Subsequently, Van der Weyden and Kelley (15) noted four species of ADA with different molecular weights in human tissue. One form of the enzyme in human tissue was particulate and appeared to be associated with the plasma membrane (15-17). Three forms of the enzyme were soluble and interconvertible with apparent molecular weights of 36,000 (sma11), 114,000 (Intermediate) and 298,000 (large). As observed by Akedo et a1, the small form of ADA, which represents the protomer (18), was convertible to the intermedlate and large form only in the presence of another protein, which had a molecular weight of 200,000 and exhibited no ADA activity. This conversion of the gmall form to the large occurred at $4^{\circ}$, exhibited a pH optimum of 5.0 to 8.0 and was associated with a logs of "conversion factor" (15). In the absence of "conversion factor" the large spectes disaggregated to the intermediate and small form (15). In accordance with these findings, the small form of ADA predominates in tissue preparations exhibiting the higher enzyme specific activities but no detectable "conversion factor" while the large form predominates in tissue extracts exhibiting the lower enzyme specific activities and abundant "conversion factor". The kinetlc characterlstics of the three soluble spectes are 1dentical except for $\mathrm{pH}$ optimum which is 5.5 for the intermediate species and $7.0-7.4$ for the large and small form.

Elucidation of the Interrelationship of the different molecular forms of ADA has also helped to partly explain the electrophoretic heterogenelty. With 1soelectric focusing the small form shows two to four electrophoretic variants. The large form exhibits the electrophoretic properties of the gmall form plus three to four additional variants. However, in contrast to the findings with starch gel electrophoresis (7), no tisaue specificity of the 1soenzymes is evident other than that attributable to the presence or absence of conversion factor.

\section{Nature of the Assoclation of SCID and ADA Deficlency}

Several observations provided strong evidence that the defictency of ADA In patients with SCID was genetically determined. Reduced erythrocyte ADA activity was noted among relatives of children with SCID and ADA defir lency $(3,19,20,21)$ with a pattern suggesting transmisston of the defect as an autosomal mendelian trait. In addition, the electrophoretic 
mobility of ADA in fibroblast extracts from apparent heterozygotes corresponded to that observed in fibroblast extracts of the relevant homozygote $(22,23)$. ADA activity, however, has been noted to be normal in red cell lygates of the parents of at least two children with SCID and ADA deficiency $(24,25)$. In one of these familles (25), but not the other (24), the deficlency of ADA appears to be due to the presence of an Inhibitor. These observations suggest that different mutations and perhaps even different molecular mechanisms may lead to a deficiency of ADA in patients with SCID.

One of the intial proposals to account for the association of ADA deficlency and SCID was a genetic deletion or a frameshift mutation involving both the locus for ADA and a linked locus critical for Immune function (1). This hypothesis was based on the observations that the loci for ADA and HLA might be linked (26) and that one type of lmmune responder gene was linked to HLA (-27). The subsequent assignment of the loc1 for ADA and the HIA complex to human chromosome 20 and chromosome 6 , respectively (28), rendered this proposition less 11kely. Although Identification of these loci to different chromosomes did not exclude the possibility that ADA deficiency was due to a large deletion or frameshift mutation, strong evidence against this was provided by the ' finding of residual ADA activity in tissue (24) and fibroblast cell strains $(22,23)$ from patlents with ADA deficlency and SCID. In the splenic t1ssue of one patient with SCID, $0.5 \%$ of normal ADA activity was noted (24). The bulk of this residual activity was found to have the molecular and kinetic properties of the intermediate form of the enzyme. Thus, in contrast to the normal enzyme, this mutant form of ADA did not aggregate to the large form nor disgociate to the small form (24). Residual ADA activity has now been reported in fibroblasts from five additional patients with SCID and ADA deficlency $(22,23)$. Although the kinetic characteristics and molecular weights of the ADA in each of these cell strains were indistinguishable from normal $(22,23)$, the electrophoretic mobility and heat lability of the ADA from these cells differed from that displayed by the wild-type enzyme. The demonstration and characterlzation of residual ADA activity in various tissues of patients with SCID thus not only provided evidence against the deletion hypothesis, but led to the suggestion that the mutations involved a gene or genes which affect the structure of ADA. Thus the deficiency of ADA appears to be the primary genetic defect.

Mechantsms Whereby the Deficiency of ADA Act1vity Regults in the Expression of SCID

Several observations suggest that ADA may be of importance in cell proliferation and/or differentiation. Exogenous adenosine and/or inhtbitor of ADA activity depress the viability and function of 1ymphoblasts (29-32), macrophages (33, 34) and fibroblasts (29) in cell culture. In addition, exogenous ADA activity stimulates the depressed in vitro response of mononuclears from a patient wth SCID and ADA deficlency to specific mitogens (35). The toxicity of adenosine accumulation has been postulated to be secondary to an induced state of "pyrimidine starvation" since (a) there is a reduction of the intracellular pyrimidine di- and tri-phosphate pool and (b) the toxicity can be prevented by the addition of the pyrimidine nucleosides, uridine or cytidine. Inhibition of pyrimidine blosynthesis de novo In this situation has been postulated to be due to a block in the conversion of orotic acid to orotidine 5'-monophosphate secondary to adenosine mediated depletion of phosphoribosylpyrophosphate (PP-ribose-P) (36). These findings have led to speculation that the Immune dysfunction associated with ADA defictency may be improved by uridine administration. 
There are several major questions which remain to be resolved. Are the effects of adenosine specific or Just a reflection of nonspecific toxicity and cell death? Are immunocytes particularly sensitive to this effect of adenosine? If the trmune dysfunction in ADA deficiency is due to Inhibition of pyrimidine blosynthsis de novo then how does one account for the following observations: (a) Immune deficlency is not a hallmark of congenital orotic aciduria secondary to orotate phosphoribosyltransferase and orotidine 5'-phosphate decarboxylase deficiency (37) or of PP-ribose-P synthetage deficlency (38), (b) megaloblastic hemopolesis occurs with inhibition of pyrimidine blogynthesis while the bone marrow is normoblastic in SCID due to ADA deficiency, (c) orotic aciduria does not occur in SCID and ADA defictency $(39,40)$, and (d) urldine falls to augment the depressed response to spectfic mitogens of mononuclears from pattents with SCID and ADA deficiency $(3,35)$ ?

A posstble unifying concept for the effect of ADA deficiency, whether due to a mutation or metabolic inhibition, is a disturbance in cAMP metabolism. Firm evidence exists that adenosine and cAMP metabolism are intricately related (41-44) and a marked increase In cAMP levels has been shown in fibroblast extracts of a patient with SCID and ADA deficiency (45). Furthermore, cAMP accumulation has a negative effect on both Iymphocyte proliferation and PP-ribose-P synthetase activity $(46,47)$. Wolberg et al (33) have demonstrated that the destruction of murine ascites leukemia cells in vitro by specifically sensitized lymphocytes can be Inhtbited by adenosine. This phenomenon is potentiated by metabolic inhibitors of ADA and is accompanied by an increase in cAMP levels in the effector cells. In the light of these findings it has been suggested that the absence of ADA activity may render lymphold cells particularly sensitive to inhibition of an effector mechanfsm mediated through adenosine cAMP accumulation. Complimenting these findings has been the demonstration that monocyte - macrophage maturation is accompanied by a 2 to 9 fold increase In ADA activity (34); incubation of monocytes with cAMP blunts the monocyte-macrophage maturation process.

In conclusion, many studies are beginning to suggest a potentially important relationship between ADA and the immune system. The further elucidation of the preclse role of this enzyme In immune function promiseg to be a most exc1ting chapter in human immunobiology.

\section{ACKNOWLEDGEMENTS}

The authors acknowledge support from the National Institutes of Health (AM 16971), the National Foundation (1-393), and the Nationa1 Health and Medical Research Counctl of Australla.

\section{REFERENCES}

1. E.R. GIBLETT, J.E. ANDERSON, F. COHEN, B. POLLARA, and H.J. MEUWISSEN, Lancet 2 1067-1069 (1972).

2. B.B. KNUDSEN and J. DISSING, Clinical Genetics 4 344-347 (1973).

3. R. PARKMAN, E.W. GELFAND, F.S. ROSEN, A. SANDERSON, and R. HIRSCHHORN, New Eng. J. Med. 292 714-719 (1975).

4. H.J. MEUWISSEN, B. POLIARA, and R.J. PICKERING, J. Pedlatr 86 169-181 (1975).

5. N. SPENCER, D.A. HOPKINSON, and H. HARRIS, Ann. Hum. Genet. 32 9-14 (1968).

6. N. RESSLER, Clin. ChIm. Acta 24 242-251 (1969).

7. Y.H. EDWARDS, D.A. HOPRINSON, and H. HARRIS, Ann. Hum. Genet. 35 207-219 (1971).

8. H. AKEDO, H. NISHIHARA, K. SHINKAI, K. KOMATSU, and S. ISHIKAWA, B1och1m. 
Biophys. Acta 276 257-271 (1972).

9. W.R.A. OSBORNE, and N. SPENCER, BHochem. J. 133 117-123 (1973).

10. R.P. AGARHAL, S.M. SAGAR and R.E. PARKS, Jr., Blochem. Pharmac. 24 693701 (1975).

11. P.F. MA, and T.A. MAGERS, Int. J. Blochem. 6 281-286 (1975).

12. H. NISHIHARA, S. ISHIKAWA, S. SHINKAI, and H. AREDO, Blochem. Blophys. Acta 302 429-442 (1973).

13. R. HIRSCHHORN, Y. LEVYTSRA, H.J. MEUWISSEN, and B. POLLARA, Nature New B1o1. 246 200-202 (1973).

14. M.B. VAN DER WEYDEN, R. H. BUCKLEY, and W.N. KELLEY, B1ochem. B1ophys. Res. Commun. 57 590-595 (1974).

15. M.B. VAN DER WEYDEN, and W.N. KELLEY, J. Biol. Chem. (1976) In Press.

16. E.G. TRAMS, and C.J. LAUTER, Blochem.

17. C.-C. LI, and J. HOCHSTADT, J. B1ol. Chem. 251 1175-1180 (1976).

18. R. HIRSCHHORN, J. Cl1n. Invegt. $5566 \overline{1-667}$ (1975).

19. C.R. SCOTT, S. - H. CHEN, and E.R. GIBLETT, J. Clin. Invest. 53 1194-1196 (1974).

20. R. HIRSCHHORN, N. BERATIS, R.S. ROSEN, R. PARKMAN, R. STERN, and S. POLMAR, Lancet 1 73-75 (1975).

21. S.-H. CHEN, C.R. SCOTT, and E.R. GIBLETT, Am. J. Hum. Genet. 26 103-107 (1974).

22. S.-H. CHEN, C.R. SCOTT, and K.R. SWEDBERG, Am. J. Hum. Genet. 27 46-52 (1975).

23. R. HIRSCHHORN, N. BERATIS, and R.S. ROSEN, Proc. Nat. Acad. Sc1. USA 73 218-217 (1976).

24. M.B. VAN DER WEYDEN, and W.N. KELLEY, in Proceeding of the Second International Purine Symposium, Vienna (1976) In Prese.

25. P. TROTTA, E.M. SMITHWICR, and M.E. BALIS, Proc. Nat. Acad. Sc1. USA 73 104-108 (1976).

26. J.H. EDWARDS, F.H. ALLEN, K.P. GLENN, L.U. LAM, and E.B. ROBSON, in Histocompatibility testing, Munksgaard, Copenhagen 1973, 00 745-751.

27. B.B. LEVINE, R.H. STEMBER, and M FOTINO, Science 178 1201-1203 (1972).

28. J.A. TISCHFIELD, R.P. CREAGAN, E.A. NICHOLS, and F.H. RUDDLE, Hum. Hered. 24 1-11 (1974).

29. H. GREEN, and T.-S. CHAN, Sclence 182 836-837 (1973).

30. I.H. FOX, E.C. KEYSTONE, D.D. GLADMAN, M. MOORE, and D. CANE, Immun. Comm. 4 419-427 (1975).

31. D.A. CARSON, and J.E. SEEGMILLER, J. C11n. Invest. 57 274-282 (1976).

32. T. HOVI, J.R. SMYTH, A.C. ALLISON, and S.C. WILLIAMS, Clin. Exp. Immunol. 23 395-403 (1976).

33. G. WOLBERG, T.P. ZIMMERMAN, K. HIEMSTRA, M. WINSTON, and L.C. CHU, Sctence 187 957-959 (1975).

34. D. FISCHER, M.B. VAN DER WEYDEN, R. SNYDERMAN, and W.N. KELLEY, J. ClIn. Invest. (1976) In Press.

35. S.H. POLMAR, E.M. WETZLER, R.C. STERN, and R. HIRSCHHORN, Lancet 2 743-746 (1975).

36. K. ISHII, and H. GREEN, J. Cell Sc1. 13 429-439 (1973).

37. KELLEY, W.N., L. H. SMITH, JR., In J.B. Stanbury, J.B. Wyngaarden, and D.S. Fredrickson (Ed), Metabolic Basis of Inherited Dlseases, (McGraw-H111, New York, in press).

38. Y. WADA, Y. NISHIMURA, M. TAKABU, Y. YOSHIMURA, K. IINUMA, T. YOSHIDA, and T. ARAKAWA, Tohoku J. Exp. Med. 113, 149-157 (1974).

39. M.B. VAN DER WEYDEN, and W.N. KELLEY, Unpublished observations.

40. F.C. SCHMALSTEIG, G. MILLS, and R.M. GOLDBLUM, C1In. Reg. 24 69A (1976).

41. A. SATTIN, and T.W. RALL, Molec. Pharmac. 6 13-23 (1970).

42. H. SHIMIZU, and J.W. DALY, Blochtm. Biophys. Acta 222 465-473 (1970).

43. D.C.B. MILLS, and J.B. SMITH, Blochem. J. 121 185-196 (1971).

44. M. HUANG, and J.W. DALY, Life Sclences $\overline{14}$ 489-503 (1974).

45. R.M. GOLDBLUM, F.C. SCHMALSTEIG, A NELSON, T. MONAHAN, and G. MILLS 
Clin. Reg. 24 68A (1976).

46. R. HIRSCHHORN, J. GROSSHAN, and G. WEISSMAN, Proc. Sc1. Exp. B101. Med. 133 1361-1365 (1970).

47. D.A. CHAMBERS, D.W. MARTIN, Jr., and Y. WEINSTEIN, Cell 3 375-380 (1974). 